近藤誘導分化プロジェクト中間評価報告書

総括責任者： 近藤寿人 (大阪大学細胞生体工学センター センター長)

研究体制：＼cjkstart分化シグナルグループ 研究員 高田慎治他 2 名 分化変異グループ 研究員 清木 誠他3名 分化遷移グループ 研究員近藤寿人他1名

評価委員： 浅島 誠 東京大学大学院総合文化系研究科 教授

黑岩 厚 名古屋大学理学研究科 教授

長濱嘉孝 岡崎国立共同利用研究機構基礎生物学研究所 教授

1. 研究の進捗状況と今後の見込み

1-1. 全体の評価

本プロジェクトは近年兴の展開がめざましい発生学の分野において、弚の複雑化・高次 構造形成過程に焦点を当てこのプロセスを司る調節機構を解明するべく計画されている。 本プロジェクトのひとつの柱はこの高度化プロセスを支える組織間相互作用と遺伝的プロ グラムについてモデルシステムを設定して行われる研究である。この機構の主要な構成要 素となる「シグナル因子」及び「転写調節因子」に着目して、発生における多樣化の主要 因すなわち「細胞分化」過程の共通の機構を解明しようというものである。これまでの研 究成果により私たちが既に光の概要を理解し、詳細な機構に迫る研究が鋭意なされている 一方で、このような研究によって初めて照らし出された未知なる領域も存在することも事 実となっている。本プロジェクトのもう一つの柱は、高次構造形成プロセスに関わる分化 調節機構を個体レベルで網羅的に解析することにより、未知の機構、未知の遺伝子の解明 を手がかに高度化機構を明らかにしてゆくことに設定されている。

このテーマでのアプローチは以下の具体的なテーマに沿って展開しているが、大学には ない ERATO の強み (すなわち、総括責任者の能力を正しく評価し、成熟した人材からな る集中的研究グループを作ることができる)により、卓越した研究グループを構築した点、 また突然変異の系統的分離という大がかり、かつリスクを恐れぬ挑戦的なプロジェクトを 積極的に進展させかつ効率的に展開している点が高く評価される。

1-2. 研究構想の具体化状況

本研究プロジェクトの遂行は、次の 3 研究グループの協力体制によって行われている。(1) 「分化シグナルグループ」では分化における組織間相互作用を担うシグナル伝達因子、(2) 
「分化変異体グループ」では分化調節に関わる未知の機構と遺伝子を探索するための突然 変異体の作出、(3)「分化遷移グループ」では組織再生過程に着目した分化機構に焦点を絞 り、乥れ午れ誘導分化という大テーマに向けて研究が展開されている。活発な研究活動に 支えられた着実な進捗状況を見せている各研究グループの活動状況の報告を以下に行う。

（1）分化シグナルグループ

この研究グループでは、組織間相互作用による分化誘導の機構をシグナルのタイプで類 別することを目的とする。対象とする系を分泌性タンパク質である Wnt 及び FGF のシグ ナル因子に絞って研究を展開している。先ず、ノックアウトマウスの解析から、Wint (Wnt-1 とWnt-3a) シグナルか背側脊髄の神経細胞の特異化に必要であることをはじめて示し、こ れによりWnt シグナルが神経管の背腹軸極性決定に重要な役割を担っていることが明らか となった。さらに、神経幹細胞の培養系を用いることで、Wnt-3a タンパク質が神経細胞の 分化を促進する働きがあることを見出し、これまで知られていない終脳におけるWnt 遺伝 子の役割の解析系を切り開いた。また、Wnt のシグナル伝達系に関しては、Wnt の分子種 ごとに異なるシグナル伝達系が働き、关れらの特異性は Wnt / Frizzled 以外の分子が担っ ていることを示した。さらに、これまで困難とされてきたWnt タンパク質の調製を、マウ ス L 細胞を用いて可能にした。これらの研究に加えて、ゼブラフィッシュを用いた突然変 異体スクリーニングの研究から、尾芽や中胚葉由来の組織に異常のある突然変異体を作出 することに成功し、現在これらの変異体と Wnt シグナル系、FGF シグナル系との関連につ いて解析している。

（2）分化変異グループ

この研究グループでは、代表的実験モデル動物である 2 種の小型魚類（ゼブラフィッシ ユとメダカ) を用いて、化学変異源 (ENU) による点突然変異を導入することにより、突 然変異体を作出し、さらに光れらを詳細に解析することを通して、分化誘導機構を系統化 することを目的としている。先ず、大量スクリーニングのために必要な小型魚類を効率的 に飼育するための水槽システム、さらにはスクリーニング作業のデータベース化を構筑し、 すでに高度なシステムを立ち上げた。接合体遺伝子に関する大規模な突然变異体スクリー ニングの対象としてメダカを選択し、またゼブラフィッシュについては、すでに国内外で 実施されているプロジェクトとは違い、特定の表現型、特に母性遺伝子の突然変異体に絞 ってスクリーニングが実行されている。これらの大規模スクリーニングはすでに軌道に乗 っており、ゼブラフィッシュとメダカの双方で新規な変異体が多数作出されている。ゼブ ラフィッシュの母性変異についてはさらに分子レベルでの研究が展開されている。メダカ においてはゼブラフィッシュの研究では報告のない興味深い中枢神経系の表現型を示す変 異体が数多く分離されている。また、生殖細胞に特異的発現を示すVasa 遺伝子を GFP で 標識したトランスジェニックメダカ系統を駆使したスクリーニングにより、始原生殖細胞 
の移動過程や数に異常を示す新規突然変異体の作出に成功していることは注目される研究 成果といえる。このような突然変異体のスクリーニングは 2002 年 9 月まで継続され、光れ 以後の残りの期間で、得られた変異体の解析、特に原因遺伝子を単離する計画が立てられ ている。

（3）分化遷移グループ

この研究グループでは、分化遷移現象から細胞分化の原理を明らかにすることを目的と している。特に、水晶体へのさまざまな分化誘導経路を、転写制御因子の視点から解析し ているが、これまでの優れた研究成果の一つとして、ゼブラフィッシュ yot 突然体で起きる 下垂体原基から水晶体への分化遷移を証明した。これに基づいて、複数の転写調節因子の 組み合わせにより分化経路が選択されるという機構を明らかにした。また、両生類におけ る水晶体の再生過程の研究については、先ずイモリ水晶体の再生が、角膜の切創ではなく 水晶体の除去により開始されることを示した。さらに、GFP 遺伝子を用いたトランスジェ ニック Xenopus 胚の効率的な作出法を確立するとともに、高温処理により導入遺伝子を自 由に誘導させる系を確立した。この系を駆使することにより、Pax6 トランスジェニック Xenopus の幼生に、さまざまな程度の単眼化を誘導することに成功している。

\section{1-3. 未知の課題への挑戦状況}

本研究プロジェクトで用いられているアプローチはいずれも非常に斬新的であり、「細胞 分化の基本的原理の探求」という発生生物学における未踏研究課題を果敢に挑むのに相応

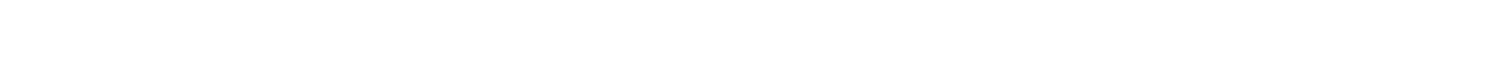
ら変異体を系統的にスクリーニングし、それらの原因遺伝子を突き止めるという試みは、 個体レベルから遺伝子レベルまでの全過程を把握することにより細胞分化の基本的原理を 探求する上での強力な方法論を提供する。

\section{1-4. 研究者の参集状況}

3 研究グループともに、総括責任者とグループリーダーの優れた統率力のもとに適切な 研究チームが結成されている。「分化シグナルグループ」と「分化遷移グループ」に関して は、両研究者のこれまでの実績を基盤として効率的な研究体制が組まれている。一方、「分 化変異グループ」については、魚 (突然変異体) の飼育、維持さらには光れら変異体の系 統的なスクリーニングを効率的に行なうために技術員を多数雇用している。各グループの 研究者は高水準な研究実績があり、光の能力が十分に生かされる形で研究が展開している。 また、グループリーダーはメダカの発生学、遺伝学、ゲノミクスに関する国内外の専門家 と常に情報の交換を通して交流している。しかし、メダカの発生・遺伝学に関する他の国 内研究プロジェクト (特定研究 B、C) 間での交流は、いずれもがほぼ同時期に発足したこ ともあり、現在のところ十分とはいい難い。今後、メダカの発生学、遺伝学が国内外で圧 
倒的な発展を遂げるためには、個々の研究者間や各プロジェクト間における尚一層の有機 的連携体制が確立されることを強く期待する。今後の研究の展開状況に依存した人員の再 配置・再募集なども必要とされるであろうが、柔軟に対処してゆくことか望ましい。

\section{1-5. 施設・設備の整備状況}

本研究プロジェクトを実施するための申し分のない施設及び設備が整備されている。特 に、安定かつ効率の良い魚類の飼育システムとしての 5,000 個に及、水槽を有する施設整 備は、大規模な突然変異体のスクリーニングの展開にとって必要不可欠なものといえよう。 さらにはこれまでの経験に基づいた突然変異体の大規模スクリーニングのための情報管理 システムの構築は、国内での先駆けとなるものであり、これを比較的短期間で完成させた ことは高く評価されてよい。事業団の支援体制とあわせ、ERATO が揭げる学際的研究チー ムによる「合宿型」の研究活動を実現させるための「場」としては理想的といえる。

\section{2 . 研究成果の現状と今後の見込み}

本研究プロジェクトは 3 研究グループ (分化シグナル、分化変異、分化遷移) から構成 される。そのうち、「分化シグナルグループ」と「分化遷移グループ」の研究課題について は、プロジェクト発足前までに高田グループ (Wnt 分子種) と近藤グループ (水晶体分化) により蓄積されてきた研究成果の一部を基盤として、本研究プロジェクトとして独立に設 定されたものである。従って、これらのグループでは、プロジェクト開始直後から活発な 研究活動がなされており、すでに前述したような優れた研究成果を着実にあげている。ま た、今後の研究方針についても、明確な道筋が示されておりプロジェクト終了時までには、 多大な研究成果が蓄積されるものと判断される。分化シグナルグループ」に関しては、Wnt の機能についてノックアウトを用いた個体レベルでの解析に加えて、タンパク質レベルの 生化学的研究に著しい進展がみられる。これまで、Wnt についてのタンパク質レベルの研 究はきわめて少ないので、今後この視点からの研究を特に推進することて際立った創造性 を発揮されることが期待される。また高田によってオリジナルに確立された方法で調製さ れた可溶性活性 Wnt タンパク質は、極めて広範囲な有用性を持ち、樣々な研究室から試料 提供要請があり、これに答え供給を行っている。本プロジェクトでの研究成果が、基盤的 な知の集積のみならず医・薬への知的、物質的展開に向けた核となる可能性が高いことを 示している。今後の研究展開においては、組織間相互作用過程を司る他のシグナル系との 関連について示すことができれば、いっ关う広い理解が得られるのではないかと期待され る。「分化遷移グループ」については、再生現象や突然変異体動物にみられる分化状態間の 遷移を探索し、光の機構を解明するというきわめてユニークなアプローチから細胞分化の 基本的原理を明らかにしようとする研究が効率的に推進されており、今後のさらなる発展 に大きな期待が集まる。これらの研究は再生医療の発展にも大きく貢献することができる 貴重な成果である。またトランスジェニック両生類の再生研究への応用の試みは新たな方 
法論を展開するものとして期待される。

一方、「分化変異グループ」については、本プロジェクトの開始にあたって新たに計画さ れた研究であり、科学技術の芽を積極的に生み出すことを目的とした ERATO にふさわし い研究グループといえる。試験的なスクリーニングの段階でもすでに多数の興味ある新規 突然変異体が作出されている。歴史的には、ショウジョウバエの形態形成に関わる突然変 異の系統的な分離と光の表現形の分類が、关れ自体で形態形成プロセスを解き明かす突破 口となった。ドイツやアメリカで行われたゼブラフィッシュ突然変異の系統的分離は、脊 椎動物の中枢神経系の形成機構を探る手がかりとなった。しかしながら魚類のゲノムが部 分四倍体であることにより表現型によるスクリーニングには限界があった。本プロジェク トではメダカという部分四倍体の樣相がゼブラフィッシュとは異なると思われる種を用い て、予測通りゼブラフィッシュでは見つからなかった変異が多種分離されており、これら の表現型を相互に比較し組み合わせることにより、中枢神経系の形態形成プロセスの像が 浮かび上がってくるものと思われる。

また性染色体による確固とした遺伝的性決定機構が確立しているメダカとは対照的に、 性決定メカニズムが柔軟で、不明のまま残されているゼブラフィッシュを用いたのでは、 現在のところ性決定や生殖細胞分化機構の研究は困難であると考えられている。GFP で標 識された生殖細胞を生きたままでモニターできるトランスジェニックメダカを用いてのス クリーニングは、ゼブラフィッシュに限らず脊椎動物全体を通しても他には例がないきわ めて創造的な研究である。

このようにして得られた突然变異体のなかから、性決定、生殖腺の性分化、生殖細胞の 発生や分化、さらには脳の性分化を制御する新規遺伝子が発見され、光れらの発生、細胞 分化における働きが解明されることにより当該研究分野の発展に大きく貢献すると考えら れる。本プロジェクトで分離された突然変異体は、兴の記述や系統が確実に保存されまた 人類共通の資産として他の研究プロジェクトに提供できるようになれば、思いもつかぬよ うな分野への貢献があるものと期待される。

順風満帆で分化変異グループは進行しているがただひとつ気になる点は、原因遺伝子の 探索を含めた突然変異体の詳細な解析のための準備がこれまでのところやや不足している ようにも思えることである。本プロジェクトの主要目的は、突然変異体を収集することで はなく、光れらを駆使して発生、細胞分化のメカニズムの基本的原理を解明することにあ る。弚のためには原因遺伝子を探索することが不可欠であり、弚のための人的準備を、突 然変異体の作出やスクリーニングと平行して、早急に進める必要があろう。場合によって は、国内外における他の研究グループとの共同研究も考慮してよいかも知れない。またこ れまで以上に本プロジェクトの他グループとの連携が重要なものになると考えられる。

\section{3.結語}

これまで述べてきたように本プロジェクトは周到な人選の下に、研究体制の人的・設備 
的確立がなされ、順調に研究が展開され既に注目すべき成果があげられている。今後とも この展開速度を維持し、またグループ間や他の研究組織との連携を高めてゆくことによっ て予想以上の成果が上がることが期待される。

最後に、本研究プロジェクトが完了した後のことについて若干コメントする。前述した ように、本プロジェクトで整備された小型魚類の飼育と突然変異体の大量スクリーニング のためのシステムは、少なくとも国内ではこれまでに類がない優れた設備である。近畿地 方発明センターに整備された施設とともに、本プロジェクトが終了した後の有効的活用方 法を是非とも検討していただきたい。現在、日本におけるメダカの発生学、遺伝学につい ての研究が、急速に発展を遂げている。貴重な日本発信のサイエンスである。これらの研 究から、綿密な染色体地図の整備や高品質な BAC ライブライーの構築もすでになされてい て、染色体歩行やポジショナルクローニングによる突然変異体についての原因遺伝子の探 究についても十分可能となっている。本研究プロジェクトで作出される小型魚類の樣々な 突然変異体が系統的に維持・管理され、今後の国内外における発生遺伝学の研究に大きく 貢献するためにも、本施設、設備の有効的活用が期待される。弚の推進母体として科学技 術振興事業団が主導的役割を果たされることを切に希望するところである。

以上 